\title{
PERKAWINAN ADAT MERARIQ DAN TRADISI SELABAR DI MASYARAKAT SUKU SASAK
}

\author{
Hilman Syahrial Haq \\ Fakultas Hukum Universitas Muhammadiyah Mataram \\ e-mail: hilmansyahrialhaq@gmail.com \\ Hamdi \\ Fakultas Hukum Universitas Muhammadiyah Mataram \\ e-mail: hadijahijah82@gmail.com
}

\begin{abstract}
ABSTRAK
Merariq sebagai tradisi perkawinan adat di masyarakat suku Sasak ternyata menyimpan potensi konflik yang tidak jarang berakhir dengan sengketa, karena diawali dengan peristiwa memaling atau mencuri atas dasar persetujuan si gadis dari kekuasaan orangtuanya, sebagai wujud sikap ksatria sekaligus bentuk keseriusan si laki-laki untuk menikahi si gadis. Namun di tengah kelemahannya ternyata sistem merariq telah menyediakan sarana alternatif penyelesaian berupa pelaksanaan negosiasi antara perwakilan pihak calon mempelai laki-laki dengan keluarga calon mempelai perempuan yang diistilahkan dengan selabar untuk menyepakati pembayaran ajikrame dan pisuke guna menuju perdamaian para pihak.
\end{abstract}

Kata Kunci: Suku Sasak, Merariq, Selabar.

\begin{abstract}
Merariq is a customary law of marriage in Sasak society, this Merariq turned out to potentially create conflict that is commonly ended up with a dispute. The reason is because it begins with the events of rob (steal) on the consent of the girl approval from the power of her parents. The rob (steal) be done as a form of chivalry of the man's seriousness marrying the girl. But amid that weakness, Merariq has provided an alternative dispute settlement by the process of negotiation between the representatives of the prospective groom to the bride family, which are termed selabar to agree on payment ajikrame and pisuke towards peaceful relationship between the parties.
\end{abstract}

Keywords: Sasak, Merariq, Selabar.

\section{PENDAHULUAN}

Mayoritas penduduk yang mendiami Pulau Lombok merupakan Suku Sasak yang umumnya beragama Islam dan memegang teguh nilai-nilai budaya. Selain itu terdapat juga Suku Bali, Mbojo, Jawa, dan berbagai suku lain yang umumnya datang dan menetap di Lombok. Secara sosio-cultural masyarakat Lombok lebih dekat kepada Jawa dan Bali, hal ini terlihat dari sistem pertanian dan kesenian yang berkembang di Lombok. Adanya pengaruh Jawa di Lombok disebabkan karena pada masa lalu Lombok merupakan bagian dari wilayah Kerajaan Majapahit. Sedangkan pengaruh budaya Bali masuk melalui penaklukan secara politik yang dilakukan oleh Kerajaan Karang Asem terhadap Kerajaan Selaparang Lombok pada abad ke $16 .^{1}$

Umumnya ekonomi masyarakat Lombok bertumpu pada sektor pertanian yang tanah garapannya berbentuk sawah yang dilengkapi dengan sistem irigasi teknis dan sebagian besar menanam padi. Sebagai masyarakat agraris, kehidupan masyarakat Sasak masih tetap mempertahankan nilai-nilai tradisional atau traditional indigenous seperti kekerabatan dan kegotongroyongan dalam mengerjakan sawah maupun upacara adat.

\footnotetext{
${ }^{1}$ Widodo Dwi Saputro dkk, Balai Mediasi Desa, Perluasan Akses Hukum dan Keadilan untuk Rakyat, LP3ES \& NZAID, Jakarta, 2007, h. 115.
} 
Tradisi tersebut tidak hanya berlaku pada aspek ekonomi saja tetapi juga dipraktikkan dalam perkawinan adat merarik. Merarik merupakan salah satu cara masyarakat suku Sasak melangsungkan perkawinan yang diawali dengan janji antara wanita dan perjaka yang telah terikat dalam hubungan beberaye atau berpacaran, untuk melarikan sang gadis dari rumahnya tanpa sepengetahuan orangtua, kerabat lainnya dan pihak-pihak yang diduga dapat menggagalkan niat tersebut. Peristiwa ini dilakukan pada malam hari. Calon suami dibantu oleh orang yang dipercaya untuk membawa calon istri ke tempat peseboan atau persembunyian, yaitu rumah keluarga calon mempelai laki-laki.

Guna mencegah terjadinya konflik atas peristiwa tersebut, maka oleh adat disediakan sarana alternatif penyelesaian masalah melalui pelaksanaan negosiasi atau selabar antara pihak laki-laki dengan keluarga sang gadis berkenan dengan keinginan dan harapan mereka untuk melangsungkan pernikahan. Berangkat dari uraian tersebut, penulis akan membahas tentang praktik perkawinan adat merarik dan tradisi selabar dari sudut pandang Hukum Islam.

\section{METODE PENELITIAN}

Penelitian hukum yang digunakan dalam penelitian ini adalah yuridis empiris. Untuk menjawab permasalahan digunakan pendekatan perundangundangan atau statute approach, pendekatan sejarah atau historical approach, Pendekatan konseptual atau conceptual approach. Adapun Jenis dan sumber bahan hukum yang digunakan dalam penelitian ini adalah bahan hukum primer, bahan hukum sekunder dan bahan hukum tersier sedangkan data diperoleh dari lapangan dengan wawancara.

\section{PEMBAHASAN}

Suku Sasak merupakan penduduk asli dan kelompok etnik mayoritas yang mendiami Pulau lombok. Mereka meliputi lebih dari 90\% keseluruhan penduduk Lombok. Kelompok-kelompok etnik lain seperti Bali, Sumbawa, Jawa, Bugis, Arab, dan Cina adalah para pendatang. ${ }^{2}$

Lombok Mirah atau Gumi Selaparang merupakan sebutan untuk pulau Lombok, di mana masyarakat Sasak melakukan serangkaian proses kehidupan dari generasi ke generasi. Adapun asal-usul suku Sasak

\footnotetext{
${ }^{2}$ Erni Budiwanti, Islam Sasak Wetu Telu Versus Waktu Lima,
} LKIS, Yogyakarta, 2000, h. 6. adalah ras Mongoloid. Ras Mongoloid adalah sub ras Melayu-Indonesia tersebar di sebagian besar wilayah Indonesia terutama yang terletak di bagian barat dan selatan antara lain; Sumatera, Jawa, Bali, dan Lombok. ${ }^{3}$

Ada juga dugaan bahwa leluhur orang Sasak adalah orang Jawa, hal ini dapat dibuktikan dengan tulisan Sasak yang disebut Jejawen. Kedatangan orang Jawa ke Lombok diperkirakan pada zaman Medang, saat pengembangan agama Islam oleh para wali-wali dari Jawa sekitar abad XV dan XVI. Dasar pemikiran ini menyimpulkan bahwa yang menjadi dasar pikiran orang-orang Sasak pada masa-masa perkembangannya adalah kebudayaan Jawa sebelum dan sejaman dengan Majapahit dan kemudian agama Islam. $^{4}$

Pada masa berikutnya Lombok kemudian di bawah raja-raja Karang Asem Bali (1740), yang memberi corak pergaulan Hindu dan Islam di Lombok. Pada waktu kekuasaan raja-raja Bali di Lombok selain terdapat kerjasama yang baik, namun sekalipun diketahui banyak terjadi peperangan atau perlawanan yang dilakukan oleh orang-orang Sasak yang beragama Islam atas kesemena-mena kerajaan Bali. Nilai yang dibawa oleh adat istiadat Hindu Bali telah banyak memberikan sumbangan bagi perkembangan adat istiadat di Lombok di kemudian hari. Tahun 1895, Lombok jatuh ke tangan Belanda, namun pemerintah Belanda tidak memberikan peranan penting dalam rangka kebudayaan dan adat istiadat, karena hanya bersifat pemerintahan yang bertujuan untuk kepentingan material belaka. ${ }^{5}$

Sebelum kedatangan pengaruh asing di Lombok, nenek moyang orang Sasak percaya bahwa setiap benda memiliki roh atau animisme, hal ini dibuktikan dengan penemuan situs penguburan di Gunung Piring yang berada di daerah perbukitan. Menurut mereka, di bukit-bukit yang tinggi tersebutlah nenek moyang bersemayam. Selain itu mereka percaya bahwa setiap benda memiliki kekuatan gaib. Seiring dengan banyaknya pengaruh dari luar, maka integrasi kepercayaan lokal dengan luar menimbulkan adanya sinkretisme dalam ajaran-ajaran yang telah dianut

${ }^{3}$ Sudirman, Gumi Sasak dalam Sejarah, Yayasan Budaya Sasak Lestari, Lombok Timur, 2007, h. 4.

${ }^{4}$ Tim Peneliti Depdikbud, Adat dan Upacara Perkawinan Daerah Nusa Tenggara Barat, Departemen Pendidikan dan Kebudayaan Pusat Penelitian Sejarah dan Budaya Proyek Penelitian dan Catatan Kebudayaan Daerah, 1978/1979, h. 21.

${ }^{5}$ Ibid., h. 21. 
sehingga muncul sistem kepercayaan yang disebut Boda ${ }^{6}$ Boda merupakan kepercayaan orang Sasak. Kendati demikian agama Boda bukan merupakan Budhisme karena ia tidak mengikuti Sidartha Gautama atau Sang Budha sebagai figur utama pemujaannya maupun terhadap ajaran pencerahannya, melainkan kepercayaan Boda ditandai dengan anemisme dan panteisme, pemujaan dan penyembahan roh-roh leluhur dan berbagai dewa lokal lainnya merupakan fokus utama dari sebelum praktik keagamaan SasakBoda. $^{7}$

Agama Islam dibawa pertama kalinya oleh para raja jawa muslim pada abad ke-13 ke kalangan orang Sasak Lombok dari barat laut, Islam segera menyatu dengan ajaran sufisme Jawa yang penuh dengan mistikisme. Kemudian pada abad ke-16, orang-orang Makasar tiba di Lombok Timur, kedatangan mereka mula-mula untuk berdagang, kemudian banyak di antara mereka yang bertempat tinggal dan menetap, bahkan mendirikan perkampungan, kemudian terjadilah hubungan yang intens antara pendatang dengan masyarakat Sasak, dari hubungan tersebut timbul rasa saling menghormati dan menghargai, sehingga terjadi inkulturasi dalam berbagai bidang seperti budaya dan agama. Dalam hal ini orang-orang Bugis Makasar lebih berhasil dalam mendakwahkan Islam suni bila dibandingkan dengan orang Jawa. Mereka orang-orang Bugis berhasil mengkonversikan hampir seluruh orang Sasak ke dalam Islam, meskipun kebanyakan mereka masih mencampurkan Islam dengan kepercayaan lokal yang non Islami. ${ }^{8}$

Pada masa awal Islam di Pulau Lombok kehidupan agama Islam sangat terbengkalai jika dibandingkan dengan pembinaan agama Islam di pulau Sumbawa yang masih berada pada propinsi NTB. Kebanyakan dari orang Sasak masih memeluk agama Islam yang belum sempurna, mereka menyerahkan urusan ibadahnya kepada para kiyai (pemimpin agama), golongan ini menamakan dirinya sebagai Islam wetu telu. Mereka percaya kepada Allah dan juga Nabi Muhammad, akan tetapi lebih banyak menjaga kesucian batin dan tingkah lakunya menurut ajaran nenek moyang. Selain itu mereka banyak melakukan upacara di tempat yang dianggap dihuni roh nenek moyang atau kemali, dan golongan ini sangat percaya bahwa di alam sekitar mereka terdapat kekuataan

\footnotetext{
${ }^{6}$ Sudirman, Op.Cit., h. 4.

${ }^{7}$ Erni Budiwanti, Op.Cit., h. 8.

${ }^{8}$ Ibid., h. 9 .
}

ghaib yang ditimbulkan oleh roh-roh atau para dewa. ${ }^{9}$ Selain itu mereka juga hanya mengakui tiga rukun dari lima rukun Islam: syahadat, shalat, dan puasa, dan mereka tidak mengharamkan minuman keras.

Keberadaan Islam wetu telu terus diperangi oleh para pendakwah dari golongan Islam waktu lima, usaha untuk mengikis ajaran Islam wetu telu di kalangan masyarakat Sasak dimulai sejak awal abad ke-20, mereka para tokoh dari Islam waktu lima tidak mengenal lelah dalam penyempurnaan ajaran Islam di kalangan Islam wetu telu, sehingga buah dari kegigihan para tokoh Islam waktu lima dalam mendakwahkan ajaran Islam yang sesuai dengan AlQur'an dan Al-Hadits berbuah manis, jumlah dari penganut Islam wetu telu menjadi semakin susut, dan mereka menjadi minoritas, dan sekarang keberadaaan mereka masih dapat ditemukan di Kecamatan Bayan Kabupaten Lombok Utara. ${ }^{10}$

Namun sisa-sisa dari pengaruh Animisme, Budha, dan Hindu masih dapat ditemukan dalam beberapa tata cara adat istiadat, kesenian, lingkaran hidup, dan perkawinan mereka. Walaupun sejak kebangkitan Islam kembali di Lombok pada abad ke-20 yang dipelopori para haji dan alim ulama, selain meningkatkan tauhid dan menegakkan syariat Islam, juga diserangnya adat istiadat dan kesenian secara besar-besaran, terutama yang berhubungan dengan seni tari dan musik perkusi dan tiup yang instrumennya terbuat dari perunggudan seruling, dan sebagai gantinya ialah dikembangkan rebana yang instrumennya terbuat dari kayu dan jangat, juga seni rudat yang dikembangkan pertama kali pada tahun 1920 oleh Haji Lalu Moh. Said dari Kopang Lombok Tengah sepulang beliau dari Mekkah. ${ }^{11}$ Hal ini menandakan betapa kuatnya pengaruh selain ajaran Islam di masa lampau.

Patron klein merupakan sistem yang dianut oleh masyarakat Sasak dalam sistem sosial, hal ini dibentuk akibat otoritas kekuasaan, yang mana dipengaruhi oleh pendudukan Kerajaan Karang Asem Bali terhadap kerajaan yang ada di Lombok. Secara umum sistem sosial yang terbangun dalam masyarakat Sasak terbagi menjadi dua yakni; golongan yang berada di kelas sosial tinggi disebut

\footnotetext{
${ }^{9}$ Zulyani Hidayah, Ensiklopedi Suku Bangsa Indonesia, LP3ES, Jakarta, 1996, h. 234

${ }^{10}$ Lalu Wacana dkk., Sejarah Kebangkitan Nasional Daerah Nusa Tenggara Barat, Departemen Pendidikan dan Kebudayaan, Mataram, 1991, h. 31.

${ }^{11}$ Ibid., h. 61.
} 
dengan golongan bangsawan dalam istilah Sasak adalah perwangse atau menak, sedangkan masyarakat biasa atau masyarakat kebanyakan disebut golongan masyarakat kelas bawah atau jajar karang.

Namun klasifikasi secara khusus masyarakat Sasak terbagi mnejadi tiga golongan sosial yakni; dedatuan adalah golongan yang pernah ada pada masyarakat Sasak awal, pada masa sekarang golongan ini disebut dengan komunitas perwangse atau bangsawan kelas atas, yang mana mereka diyakini sebagai keturunan langsung para datu atau raja dan bergelar raden. Klasifikasi kedua adalah golongan perbape atau bangsawan kelas menengah, golongan ini adalah hasil dari perkawinan silang antara golongan bagsawan kelas atas dan golongan yang berstrata di bawahnya dan bergelar lalu-baiq, dan gede-lale. Dan klasifikasi yang terakhir adalah jajar karang atau kaula, kelas masyarakat ini adalah golongan yang teridentifikasi sebagai masyarakat kebanyakan atau rakyat biasa, dan penyebutan amaq untuk ayah dan inaq untuk ibu, yang belum mempunyai anak disebut loq untuk laki-laki dan laq sebutan untuk perempuan. Sedangkan kaum bangsawan akan dipanggil mamiq untuk ayah dan inaq untuk ibu. Klasifikasi-klasifikasi sosial ini masih ada sampai sekarang pada masyarakat Sasak, dan merupakan sisa dari bentuk pelapisan sosial lama.

Perkawinan antara golongan perwangse/menak dengan golongan jajar karang sangat dihindari oleh para golongan perwangse/menak, apalagi calon mempelai perempuannya berasal dari golongan yang lebih tinggi yakni golongan perwangse atau menak dan calon mempelai laki-lakinya berasal dari masyarakat biasa atau jajar karang. Karena perkawinan ini dipandang oleh mereka tidak dapat mewariskan garis kebangsawanan, anak-anak yang dilahirkan otomatis akan mewariskan garis keturunan dari ayah. Karena mereka menganut perkawinan dengan sistem patrilineal, perkawinan bertujuan guna mempertahankan garis keturunan bapak, anak yang dilahirkan dari perkawinan tersebut akan ikut kekerabatan bapaknya, sehingga anak laki-laki harus melaksanakan bentuk perkawinan ambil istri dengan pembayaran uang jujur.

Dalam penggunaan bahasa, bahasa Sasak juga mengenal tingkatan bahasa yakni ada tiga tingkatan bahasa yaitu bahasa halus/utama, bahasa madya, dan bahasa biasa. ${ }^{12}$ Pada umumnya para golongan

\footnotetext{
${ }^{12}$ Zulhani Hidayah, Op.Cit., h. 233.
}

masyarakat yang berasal dari golongan perwangse atau menak menggunakan bahasa utama dan sebagian menggunakan bahasa madya dalam kehidupan sehariharinya, umumnya bahasa utama dipergunakan jika seseorang berbicara dengan orang yang dituakan. Sedangkan bahasa biasa umum dipakai oleh orang kebanyakan atau orang biasa dalam kehidupan sehari-hari. Bahasa sasak terdiri atas beberapa dialek, yaitu: dialek Sasak Pejanggi, Sasak Selaparang, Sasak Bayan, Sasak Tanjoang, Sasak Pujut, Sasak Sembalun, Sasak Tebango, dan Sasak Pengantap. ${ }^{13}$

Namun pada zaman sekarang, klasifikasi dan strata sosial ini mulai luntur, hal ini dipengaruhi oleh perkembangan zaman, sumber daya manusia, doktrin agama, dan proses pertukaran sosial yang semakin menunjukkan peningkatan dari masa ke masa. Sehingga mereka termasuk golongan bangsawan, tidak begitu mendapat keistimewaan dalam masyarakat Sasak.

\section{Pelaksanaan Perkawinan Adat Merariq Suku Sasak}

Perkawinan menurut hukum Islam adalah suatu akad atau perikatan untuk menghalalkan hubungan kelamin antara laki-laki dan perempuan dalam rangka mewujudkan kebahagiaan hidup keluarga, yang diliputi rasa ketentraman serta kasih sayang dengan cara yang diridhai Allah. ${ }^{14}$ Perkawinan dalam pandangan masyarakat Sasak adalah untuk menjaga kelangsungan keturuan serta memelihara harta warisan, dalam hal ini dikenal lembaga perkawinan dalam kerabat sendiri. ${ }^{15}$ Selain dari itu perkawinan juga bertujuan menyatukan kedua keluarga/kerabat. Oleh karenanya perkawinan bukan hanya urusan pribadi yang satu dengan pribadi yang lain, melainkan menjadi urusan kedua keluarga/kerabat, bahkan menjadi urusan masyarakat.

Masyarakat Sasak yang didominasi agama Islam, memandang perkawinan sebagai menjalankan suruhan agama, ${ }^{16}$ sebagai wujud ketaqwaan hamba kepada Penciptanya, karena Islam sebagai agama yang mayoritas dianut oleh masyarakat Sasak menyuruh pemeluknya untuk segera melangsungkan perkawinan bila mempunyai kemampuan untuk

\footnotetext{
${ }^{13}$ Ibid., h. 232.

14 Ahmad Azhar Basyir, Hukum Perkawinan Islam, UII Press, Yogyakarta, 2004, h. 14.

15 Tim Peneliti Depdikbud, Op.Cit., h. 25.

16 Ibid., h. 26.
} 
melaksanakannya. Islam memandang perkawinan sebagai perbuatan yang mulia yakni untuk mencegah pemeluknya dari perbuatan zina atau perbuatan terlarang dengan orang yang tidak sah, hal ini dimaksudkan agar keturunan yang dihasilkan dari perkawinan mempunyai garis keturunan yang jelas dan juga untuk menjaga ketertiban masyarakat atau umum. Dalam perkawinan yang diajarkan oleh Islam juga terkandung tujuan-tujuan yakni untuk membina keluarga dunia dan akhirat.

Sedangkan dari golongan menak atau bangsawan, selain perkawinan bertujuan seperti yang dijelaskan di atas, juga untuk mempertahankan status sosial. ${ }^{17}$ Maka dengan tujuan ini mereka tidak menghendaki perkawinan dengan masyarakat biasa, dan perempuan dari golongan menak yang melangsungkan perkawinan dengan laki-laki dari golongan biasa akan dibuang oleh keluarganya dan untuk diakui lagi sebagai bagian dari keluarga besarnya sangat sulit. Akibat dari perlakuan ini seseorang yang berasal dari golongan jajar karang akan berfikir ulang untuk menikahi perempuan yang berasal dari golongan menak atau bangsawan karena akan mendapat kesulitan dalam hubungan kekerabatan di kemudian hari. Masyarakat Sasak mengenal beberapa bentuk perkawinan, yang pada umumnya dibagi menjadi lima bentuk, ${ }^{18}$ yakni: memagah, nyerah hukum, kawin gantung, belakoq atau melamar, dan lari bersama atau memaling atau merarik.

Memagah atau disebut juga memoger merupakan bentuk perkawinan dengan cara melarikan disertai dengan paksaan serta dilakukan pada siang hari. Seorang laki-laki dengan dibantu oleh beberapa temannya membawa lari si gadis dengan paksaan ketika gadis tersebut jauh dari pengawasan orangtuanya. Terkadang pencurian tersebut dilakukan dengan membopong yang membahayakan si gadis, tidak jarang terjadi bentrokan antara pihak pemuda dan keluarga si gadis sebagai akibat dari peristiwa tersebut.

Nyerah hukum merupakan bentuk perkawinan yang dilakukan dengan cara pelaksanaan adat dan upacara perkawinan diserahkan kepada keluarga pihak gadis. Biaya perkawinan ditanggung oleh pihak perempuan, biasanya cara ini dilakukan oleh gadis sasak dengan laki-laki dari luar Sasak. Akibat dari nyerah hukum kedudukan seorang suami adalah

\footnotetext{
${ }^{17}$ Ibid.

${ }^{18}$ Ibid., h. 33.
}

sebagai pembantu rumah tangga bagi orangtua si gadis.

Kawin gantung atau kawin tadong merupakan perkawinan anak-anak, perkawinan ini dilakukan penundaan waktu untuk beberapa waktu sampai salah satu atau kedua pengantin menjadi dewasa, namun perkawinan bentuk ini sudah jarang dilakukan disebabkan perubahan zaman yang semakin maju.

Belakok atau meminang adalah bentuk perkawinan yang dilakukan dengan meminta atau melakukan peminangan seorang laki-laki kepada si gadis, kedua bentuk perkawinan terakhir adalah merupakan pengaruh ajaran Islam, yang mana dalam kawin gantung mengikuti Sunnah Rasul yang menceritakan perkawinan Nabi Muhammad dengan Siti Aisyah, sedangkan perkawinan dengan cara peminangan merupakan cara yang diajarkan oleh Islam sendiri sesuai dengan firman Allah dalam Surat Al-Baqarah ayat 235, yang menyatakan bahwa tidak ada dosa bagi kamu meminang wanita-wanita itu dengan sindiran atau kamu menyembunyikan keinginan untuk mengawini mereka dalam hatimu. Allah mengetahui bahwa kamu akan menyebutnyebut mereka, dalam pada itu janganlah kamu mengadakan janji kawin dengan mereka secara rahasia, kecuali sekedar mengucapkan (kepada mereka) perkataan yang ma'ruf. Dan janganlah kamu ber'azam atau bertetap hati untuk beraqad nikah, sebelum habis 'iddahnya. Dan ketahuilah bahwasanya Allah mengetahui apa yang ada dalam hatimu; Maka takutlah kepada-Nya, dan ketahuilah bahwa Allah Maha Pengampun lagi Maha Penyantun.

Merariq atau memaling merupakan bentuk perkawinan yang paling populer di kalangan orang Sasak. Merariq berasal dari bahasa Sasak berari yang artinya berlari, dan mengandung dua makna, yang pertama adalah arti sebenarnya dan yang kedua adalah keseluruhan dari pada pelaksanaan perkawinan menurut adat Sasak. Berari atau berlari berarti teknik atau cara, sehubungan dengan ini berarti bahwa tindakan dari melarikan atau membebaskan si gadis dari ikatan orangtuanya serta keluarganya.

Perkawinan dengan bentuk merariq muncul dari pengaruh Hindu-Bali setelah melakukan invasi terhadap Lombok pada abad 17, intimidasi kekuasaan dilakukan Bali dengan semena-mena dalam memberikan sikap terhadap wanita Sasak, yakni sebagai pemuas nafsu, perlakuan ini memunculkan inisiatif dalam diri orang Sasak terutama para 
pemudanya, dari pada wanita Sasak ini diambil oleh orang Hindu-Bali untuk dijadikan gundiknya maka lebih baik mereka atau pemuda Sasak yang membawa lari wanita Sasak untuk menyelamatkan dan dinikahinya. Pada awalnya merariq merupakan sebuah bentuk kepedulian serta keberanian pemuda Sasak untuk menyelamatkan para wanitanya dari perlakuan Bali. Dari sini terjadi dua arus akulturasi kebudayaan antara nilai kebudayaan Bali dan nilai Islam yang mana merupakan obyektifitas yang melahirkan realitas yakni merariq. ${ }^{19}$ Dalam praktiknya perkawinan merariq dibagi menjadi tiga tahapan, yaitu: tahap sebelum perkawinan, proses pelaksanaan perkawinan, dan upacara adat setelah perkawinan. $^{20}$

Tahap sebelum perkawinan dimulai dari cara pemilihan jodoh, yakni dengan cara kemele mesak dan suka lokaq. Kemele mesak atau atas kemauan sendiri adalah cara yang paling banyak dilakukan untuk memilih jodoh, dibandingkan dengan suka lokaq atau pilihan orangtua. Cara kemele mesak atau atas kemauan sendiri dimulai dengan cara melarikan atau mencuri gadis dari pengawasan wali dan lingkungan sosialnya atau induk semang terlebih dahulu, cara ini dinilai oleh sebagian masyarakat Sasak sebagai wujud atas kesungguhan si laki-laki untuk mempersunting si gadis.

Kemele mesak oleh sebagian masyarakat Sasak diyakini sebagai evidensi kelaki-lakian calon suami dengan menunjukkan keberanian, keseriusan, dan gambaran artikulasi tanggung jawab dalam perkawinan serta dalam kehidupan upacara adat setelah perkawinan nantinya. ${ }^{21}$ Selain itu banyaknya pemuda Sasak memilih cara ini disebabkan oleh kondisi sosial dengan meningkatnya otonomi anak dan terkait dengan persepsi bahwa pilihan perkawinan merupakan hak prerogatif si anak dalam menentukan pilihan jodohnya.

Namun sebelum keputusan melarikan atau mencuri gadis, pertemuan pemuda dengan pemudi

\footnotetext{
${ }^{19}$ Lalu Darmawan, Sistem Perkawinan Masyarakat Sasak (Interpretasi atas Dialetika Agama dengan Tradisi Merarik Masyarakat Lombok Nusa Tenggara Barat), Skripsi UIN Sunan Kalijaga, Yogyakrta, 2006, h. 125.

${ }^{20}$ Kaharudin, "Perkawinan Adat Merariq (Kawin Lari) Pada Masyarakat Sasak dalam Perspektif Hukum Perkawinan Islam di Nusa Tenggara Barat”, Media Hukum, Vol. 19, 2007, h. 320.

${ }^{21}$ Jhon Ryan Bartholomew, Alif Lam Mim: Recording Islam, Modernity and Traditional in an Indonesia Kampung, alih bahasa, Imron Rosyidi, Alif Lam Mim:Kearifan Masyarakat Sasak, Tiara Wacana, Yogyakarta, 2001, h. 201.
}

dilakukan dengan cara midang atau ngayo, di mana pemuda berkunjung ke rumah si gadis, untuk sekedar bincang-bincang kecil tentang banyak hal dengan ditemani oleh orang tua atau saudara dari si gadis, hal ini dilakukan untuk mencegah perbuatan atau tuduhan negatif dari masyarakat yang melihat proses midang atau ngayo.

Pelarian atau pencurian gadis baru dilakukan setelah ada kesepakatan antar pemuda dan pemudi untuk melanjutkan hubungan ke jenjang yang lebih serius yakni perkawinan. Proses ini diawali dengan pelarian atau pencurian yang dilakukan calon mempelai laki-laki kepada si gadis, untuk selanjutnya dibawa ke persembunyian yang telah dipersiapkan oleh si calon mempelai laki-laki, namun sebelum pelarian atau pencurian terlebih dahulu kedua calon mempelai sudah merencanakan untuk bertemu di tempat dan waktu yang telah ditentukannya, atau terlebih dahulu calon mempelai laki-laki mengajak si gadis ke suatu tempat misalnya ke tempat wisata atau semacamnya. Adapun tempat persembunyian yang dituju adalah rumah kerabat calon mempelai laki-laki (biasanya rumah si paman calon mempelai laki-laki).

Selanjutnya tahap pelaksanaan merariq dimulai dengan pemberitahuan kerabat yang dijadikan tempat persembunyian kepada orangtua dari calon mempelai laki-laki, untuk selanjutnya kedua calon mempelai dijemput untuk di bawa pulang ke rumah orangtua calon mempelai laki-laki.

Sebagai akibat dari pelarian atau pencurian tersebut, maka pihak keluarga calon mempelai lakilaki harus melakukan besejati. Besejati diawali dengan laporan kepada keliang atau kepala kampung oleh orangtua atau keluarga calon mempelai laki-laki. Selanjutnya informasi disampaikan oleh pembayun kepada pihak pihak keluarga perempuan melalui keliang atau kepala kampung daerah asal mempelai perempuan secepatnya. Pembayun memberitahukan kebenaran terjadinya merariq tersebut dan siapa yang telah melakukan pelarian atau pencurian tersebut, kapan, dan di mana calon mempelai perempuan dilarikan.

Berdasarkan informasi dari pembayun, keliang menyampaikan secepatnya kepada pihak orangtua atau keluarga perempuan, kemudian pihak keluarga mengadakan musyawarah tentang berbagai masalah tata krama perkawinan setempat, termasuk berbagai pembayaran yang dibebankan kepada pihak laki- 
laki. Semuanya menjadi catatan untuk kemudian disampaikan kepada utusan selabar.

Selabar merupakan proses meminta kesediaan orangtua atau keluarga calon mempelai perempuan untuk memberikan persetujuan dan perwalian terhadap kedua calon mempelai. Dalam proses selabar banyak yang harus dimusyawarahkan atau dinegosiasikan untuk mencapai kesepakatan, sehingga kepentingan kedua belah pihak keluarga atau kerabat terakomodir dengan baik. Dalam proses negosiasi, beberapa yang menjadi pembicaraan penting yakni masalah pembayaran adat yang disebut ajikrame dan pisuke.

Ajikrame merupakan sejumlah pembayaran yang telah ditetapkan oleh adat sebagai lambang dan status sosial dari pasangan mempelai dan setiap keturunan yang akan dilahirkan. Pembayaran ajikrame bersifat wajib dan menjadi upaya agar akad nikah dapat segera dilaksanakan. Sedangkan pisuke yakni permintaan pembayaran lain, seperti sejumlah uang atau barang-barang berharga, diperuntukkan untuk 'pengobat atau penyenang' sehingga pihak keluarga perempuan menjadi suke atau saling merelakan atau mengikhlaskan. Pisuke juga bertujuan sebagai penghibur rasa sedih orangtua yang akan ditinggal oleh anak gadisnya. Dengan demikian, pisuke sematamata permintaan orangtua untuk dirinya. Namun ada sebagian pendapat masyarakat Sasak bahwa uang pisuke tersebut digunakan untuk penyambutan pada acara nyongkolan dan untuk mengadakan acara syukuran atau resepsi di rumah pihak perempuan. Dalam penentuan jumlah pisuke ini menjadi rentan terjadinya konflik antara kedua belah pihak keluarga mempelai yang membutuhkan waktu serta tenaga dan pikiran.

Besejati dan selabar merupakan laku-laku adat yang ada di masyarakat Sasak yang harus dilakukan oleh pihak laki-laki sebagai akibat dari perlakuannya membawa lari atau mencuri anak gadis seseorang untuk dipersunting. Untuk menebus kesalahannya pihak laki-laki harus melakukan dua proses tersebut terutama proses selabar karena besejati dan selabar merupakan cermin kerendahan hati dan pengakuan jujur sebagai sikap tanggung jawab dan kejujuran serta momentum meminta maaf atas kesalahan yang diperbuat. Hal ini merupakan cermin dari kelonggaran adat atas masyarakat untuk melaksanakan ritual adat sebagai bukti bahwa adat itu sifatnya menyesuaikan dan memaafkan dengan keadaan dan kondisi yang ada.
Setelah kedua belah pihak mencapai kata sepakat selama proses selabar dan pihak laki-laki bersedia menunaikan apa yang diminta oleh pihak perempuan, maka proses selanjutnya adalah bait wali, di mana dalam proses ini, penghulu dari tempat kediaman si calon mempelai laki-laki pergi untuk menemui ayah atau yang dituakan di keluarga si gadis untuk dimintakan wali nikah.

Setelah adanya kepastian dan kesediaan akan wali nikah dari pihak perempuan, maka akad nikah atau ngawinang disebut juga nikahang dapat dilaksanakan, biasanya yang menjadi tempat ngawinang adalah masjid. Acara akad nikah dilaksanakan berdasarkan ketentuan hukum Islam atau figh, maka hubungan kedua mempelai menjadi sah dan diperkenankan melakukan hubungan suami istri.

Upacara adat setelah akad nikah adalah sorong serah, nyongkolan, dan balik tampak. Sorong serah secara harfiah berarti menyodorkan dan menyerahkan, adapun barang yang disodorkan dan diserahkan adalah pembayaran ajikrame dan pisuke, namun di bagian daerah Lombok yang lain misalnya di desa Kekait sorong serah dilaksanakan sebelum acara bait wali karena mereka beranggapan bahwa pembayaran aji krame dan pisuke merupakan syarat untuk pemberian wali nikah dan menandakan pihak keluarga perempuan telah memberikan restu kepada kedua calon mempelai.

Nyongkolan merupakan suatu rangkaian proses perkawinan merariq, di dalamnya terdapat upacara iring-iringan pengantin dari rumah pihak laki-laki menuju rumah pihak keluarga perempuan dengan diiringi musik-musik tradisional Sasak, misalnya rudat, gendang belek, dan kecimol. Upacara nyongkolan dilakukan setelah akad nikah atau ngawinang yang bertujuan untuk memberitahukan kepada khalayak ramai jika telah terjadi suatu perkawinan antara kedua mempelai agar di kemudian hari si laki-laki tidak lagi mengganggu atau main mata dengan gadis lain karena ia telah berstatus sebagai suami, dan begitu pun sebaliknya.

Sedangkan balik tumpak merupakan upacara yang dilaksanakan sehari setelah proses nyongkolan, dalam acara ini keluarga mempelai laki-laki berkunjung ke rumah keluarga mempelai perempuan yang diisi dengan acara silaturahmi dengan tujuan agar kedua belah keluarga saling mengenal lebih jauh. Acara balik tampak merupakan acara terakhir dari proses perkawinan merarik pada suku Sasak. 
Pada hakikatnya perkawinan bertujuan untuk membina rumah tangga yang bahagia dan kekal, oleh karena itu sebelum perkawinan dilaksanakan, maka diperlukan persetujuan dan kesukarelaan dari pihakpihak yang mempunyai hak, yakni hak orang-orang yang akan melangsungkan perkawinan dan hak wali. ${ }^{22}$ Untuk mencapai persetujuan dan kerelaan tersebut maka Islam mengajarkan khitbah atau peminangan, yakni pernyataan atau permintaan dari seorang lakilaki kepada seorang wanita untuk mengawininya, baik dilakukan secara langsung maupun dengan melalui perantara pihak lain yang dipercayai.

Oleh karena itu perkawinan dengan cara merariq atau pencurian harus dihindari dan ditinggalkan, karena Islam mengajarkan Khitbah atau peminangan. Hal yang sudah jelas bahwa melamar atau meminang merupakan cara yang diperintahkan oleh ajaran Islam, dan setiap muslim harus mengikuti apa yang telah diajarkan dalam Al-Qur'an dan Al-Hadist, sebagai dua sumber utama dalam menjalankan kehidupan bagi setiap muslim. Mengingat masyarakat Sasak juga mengenal bentuk perkawinan meminang atau Belakok yang berarti meminta ijin pada orangtua si gadis, dan sebelumnya telah ada janji perkawinan di antara keduanya, dalam pelaksanaannya orangtua si gadis pada umumnya menerima permintaan tersebut setelah mengajukan permintaan persyaratan terutama pembayaran sejumlah uang untuk biaya pesta. ${ }^{23}$ Cara ini adalah cara masyarakat Sasak melakukan perkawinan sebelum dipengaruhi oleh budaya HinduBali yang mengadakan invasi terhadap Lombok pada awal abad 17.

Perkawinan yang diawali dengan cara belakok pada masyarakat Sasak merupakan cara yang lebih dekat dengan ajaran Islam, karena dengan caaraa belakok akan menghindari terjadinya konflik, dan perkawinan didasarkan persetujuan dan kesukarelaan untuk menjamin kelangsungan rumah tangga yang akan dibangun. Sedangkan budaya merariq harus ditinggalkan, walaupun pada awalnya merupakan perilaku yang dianggap baik karena untuk menyelamatkan perempuan bangsa Lombok dari ancaman Bali. Merariq sudah tidak sesuai dengan keadaan sekarang, yang mana suku Sasak yang mayoritas beragama Islam bebas dan tidak ada

\footnotetext{
22 Soemiyati, Hukum Perkawinan Islam dan UndangUndang Perkawinan (Undang-Undang No. 1 Tahun 1974 tentang Perkawinan), Liberty, Yogyakarta, 1986, h. 22.

${ }^{23}$ Tim Peneliti Depdikbud, Op.Cit., h. 35.
}

halangan untuk menjalankan aturan yang diajarkan oleh Islam.

Organisasi keagamaan yang ada di Lombok seperti Nandathul Wathan (yang selanjutnya disebut dengan NW), Nahdatul Ulama (yang selanjutnya disebut dengan NU), dan Muhammadiyah menyikapi budaya merariq dengan melarang atau mengecam, namun pelarangan ini dilakukan dengan berbagai macam, Muhammadiyah misalnya sangat mengecam dan melarang anggotanya untuk melakukan perkawinan dengan cara merariq, sedangkan NW dan NU menyikapinya dengan mengimbau, tetapi tidak sampai melarangnya, namun jika terdapat perkawinan merariq maka diselesaikan dengan proses selabar dengan meminta kepada para pihak untuk mencari nilai kesamaan yakni mempercepat akad nikah kedua mempelai dengan aturan hukum Islam. ${ }^{24}$ Kaharudin menambahkan bahwa masyarakat Islam Sasak yang terdidik melihat dampak merariq, maka perlu dicarikan solusi alternatif yang lebih baik karena tidak ada ketentuan hukum Islam tentang praktik merariq. ${ }^{25}$

\section{Pelaksanaan Tradisi Selabar dalam Perkawinan Merariq Suku Sasak}

Selabar atau negosiasi merupakan komunikasi dua arah antara kedua pihak yakni pihak keluarga mempelai laki-laki dan pihak keluarga mempelai perempuan dalam rangka mencapai kesepakatan, di mana kedua belah pihak sama-sama memiliki kepentingan yang berbeda. Adapun kepentingan yang sama di antara kedua belah pihak adalah samasama berkeinginan agar permasalahan cepat selesai yakni kedua mempelai pengantin segera dinikahi sesuai dengan ajaran Islam. Dan kepentingan yang berbeda adalah pihak perempuan berkeinginan agar tuntutannya kepada pihak keluarga laki-laki terpenuhi, yakni berkenaan dengan pembayaran ajikrame, dan pembayaran sejumlah atau harta berharga atau pembayaran pisuke. Sedangkan pihak laki-laki menginginkan pembayaran ajikrame dan pisuke tidak begitu besar sesuai dengan permintaan pihak keluarga perempuan, diharapkan pembayaran ajikrame dan terutama pisuke sesuai dengan kemampuan finansial pihak keluarga laki-laki. Proses negosiasi atau selabar ini terbagi ke dalam

${ }^{24}$ Wawancara dengan Ahmad Baihaqi, Pegawai KUA Kecamatan Gunung Sari pada tanggal 18 Juni 2016 di Gunung Sari.

${ }^{25}$ Kaharudin, Op.Cit., h. 332. 
tiga tahapan, yakni tahap awal, tahap kesepakatan, dan tahap pelaksanaan kesepakataan.

Selabar dimulai setelah besejati. Negosiasi atau selabar adalah komunikasi dua arah di antara para pihak, yang mana pihak laki-laki diwakilkan oleh kepala lingkungan atau bawahannya yang dipandang memiliki kemampuan diplomasi, sedangkan pihak perempuan dihadiri oleh pihak keluarga yakni orang yang dituakan misalnya ayah atau paman si gadis. Proses selabar pada tahap ini dilakukan di rumah keluarga si gadis biasanya di berugaq atau semacam bale atau di teras rumah.

Komunikasi yang terjadi diawali oleh wakil dari pihak laki-laki, dengan memaparkan beberapa hal, yakni diantaranya permohonan maaf atas terjadinya pencurian atau pelarian si gadis, menyambung tali silaturahmi, dan menyelesaikan permasalahan yang terkait dengan perkawinan merariq diantaranya pembayaran ajikrame dan pembayaran uang pisuke, dan indengan wali.

Pada tahap ini, pelaksanaannya membutuhkan waktu yang panjang, berkisar antara tiga hingga lima kali pertemuan, tergantung pada penjajakan kepentingan masing-masing pihak. Namun pada umumnya dari pertemuan ke pertemuan selanjutnya terdapat jeda atau tenggang waktu yakni biasanya dua atau tiga hari. Jeda atau tenggang waktu ini berfungsi untuk memberi kesempatan kepada kedua belah pihak untuk mempertimbangkan hasil negosiasi, selain bertujuan agar pihak laki-laki mempunyai kesempatan untuk mencari kekurangan finansial. Pada akhir pelaksanaan tahap ini terjadi penyelesaian pembicaraan untuk selanjutnya dibuat kesepakatan dan pelaksanaan kesepakatan tersebut.

Negosiasi atau selabar dapat berlangsung secara efektik dan cepat menghasilkan kesepakatan sesuai dengan yang diinginkan oleh kedua belah pihak, dipengaruhi oleh kredibilitas negosiator yakni meliputi hal-hal sebagai berikut: ${ }^{26}$

Pertama, Memiliki kemampuan dalam berdiplomasi yang baik; Kedua, Memiliki kemampuan dalam berkomunikasi dan berargumentasi yang baik; Ketiga, Negosiator pihak laki-laki mengetahui aturan adat atau awig-awig gubuk, di mana tempat tinggal keluarga pihak perempuan, karena masing-masing desa terdapat aturan adat yang tidak tertulis yang berbeda-beda; Keempat, Memiliki pemahaman ajaran agama Islam dengan baik; Kelima, Memiliki kemampuan dalam menyelesaikan permasalahan; dan Keenam, Memiliki kepribadian yang baik.

Adapun ketentuan besar kecilnya pembayaran ajikrame ditentukan oleh ketetapan yang telah disepakati oleh aparat desa atau awig-awig desa, sedangkan ketentuan harga pisuke sangat beragam, namun secara umum ditentukan oleh status sosial keluarga si gadis, tingkat pendidikan yang ditempuh, dan pekerjaan si gadis. Jika seorang gadis berasal dari keluarga yang memiliki status sosial yang tinggi, si gadis menempuh pendidikan sampai perguruan tinggi dan memiliki pekerjaan yang mapan misalnya bekerja sebagai Pegawai Negeri Sipil (PNS), maka harga pisuke yang ditetapkan oleh pihak keluarga si gadis berkisar antara dua puluh sampai tiga puluh lima juta, namun sebaliknya jika si gadis berasal dari keluarga yang memiliki status sosial biasa, dan pendidikan tidak sampai perguruan tinggi, maka harga pisuke yang ditetapkan berkisar antara lima sampai sepuluh juta rupiah.

Menurut Muhirdan, jika dilihat dari teknik yang digunakan dalam komunikasi dua arah yang terbangun dalam proses selabar yakni teknik negosiasi kompetitif dan teknik negosiasi kooperatif. Adapun penyebab terjadinya teknik negoiasi kompetitif dalam selabar adalah karena adanya beberapa faktor yang terdapat dalam pihak perempuan yakni faktor ekonomi, pendidikan si gadis hingga status sosial si gadis misalnya anak seorang tokoh masyarakat.

Lebih lanjut Muhirdan menjelaskan bahwa di sebagian daerah di Lombok, misalnya di Desa Kekait negosiasi yang terbangun kebanyakan negosiasi yang bersifat kooperatif. Teknik negosiasi kooperatif menganggap pihak negosiator lawan bukan sebagai musuh, melainkan sebagai mitra untuk mencapai kesepakatan yang tidak merugikan kedua belah pihak.

Selabar atau negosiasi pada umumnya bertujuan untuk mencapai kesepakatan di antara para pihak yang bersengketa atau dalam rangka mencari perdamaian seperti yang disebutkan dalam Kitab Undang-Undang Hukum Perdata (KUHPerdata) Pasal 1851 bahwa perdamaian adalah suatu persetujuan dengan mana kedua belah pihak, dengan menyerahkan, menjanjikan atau menahan suatu barang, mengakhiri suatu perkara

26 Wawancara dengan Muhirdan, Pengasuh Pondok Pesantren Al-Adiyat Gunung Sari Lombok Barat di Mataram pada tanggal 22 Juni 2016. 
yang sedang bergantung ataupun mencegah timbulnya suatu perkara. ${ }^{27}$

Islam sebagai agama yang sempurna mengajarkan kepada penganutnya untuk melakukan perdamaian jika terdapat perselisihan di antara mereka. Perdamaian dalam Islam disebut dengan istilah islah, yakni menurut bahasa adalah memutuskan suatu persengketaan antara dua pihak yang saling bersengketa. ${ }^{28}$ Allah berfirman sebagaimana dijelaskan dalam Al-Qur'an Surat Al-Hujurat ayat 9, yang menyatakan bahwa apabila dua golongan dari mereka yang beriman itu berpegang hendaklah kamu damaikan antara keduanya, tapi kalau yang satu melanggar perjanjian terhadap yang lain, hendaklah yang melanggar perjanjian itu kamu perangi sampai surut kembali pada perintah Allah. Kalau dia telah surut, damaikanlah antara keduanya menurut keadilan, dan hendaklah kamu berlaku adil. Sesungguhnya Allah mencintai orang-orang yang berlaku adil.

Dari ayat tersebut terlihat jelas, Islam mengajarkan kepada pemeluknya bahwa perdamaian itu sangat penting dan harus dijaga, karena umat Islam yang satu dengan umat Islam yang lain merupakan saudara, dan jika terjadi perselisihan di antara mereka harus segera didamaikan, dan bagi pihak yang melanggar perdamaian tersebut, maka dalam ayat di atas diperintahkan untuk memeranginya sampai ia kembali kepada perdamaian tersebut, karena Allah menyukai orang-orang yang berbuat adil.

\section{PENUTUP}

\section{Kesimpulan}

Merariq merupakan salah satu cara perkawinan yang umum dilakukan oleh masyarakat Sasak. Tradisi ini muncul dari pengaruh budaya HinduBali setelah melakukan invasi terhadap Lombok pada abad ke 17, yang dalam praktiknya seringkali menimbulkan konflik karena dilakukan dengan cara mencuri si gadis atau berlari lari bersama tanpa diketahui oleh orangtua si gadis, kerabat atau pihak lain yang dapat menghalangi niatan tersebut. Karena itu tradisi ini dianggap bertentangan dengan ajaran Islam yang menghendaki terjadinya perkawinan di awali dengan khitbah atau peminangan, dan Salabar

\footnotetext{
${ }^{27}$ Subekti, Kitab Undang-Undang Hukum Perdata, Pradnya Paramita, Jakarta, 2008, h. 468.

${ }^{28}$ As Sayyid Sabiq, Fiqh As Sunnah Juz II, (Beirut: Dar Al Fikr, 1977), h. 305 dalam Abdul Halim, Kontekstualisasi Mediasi dalam Perdamaian, www.badilag.net di akses pada tanggal 25 Juni 2016.
}

merupakan suatu alternatif penyelesaiaan masalah yang disediakaan adat sebagai tindak lanjut dari peristiwa memaling atau merariq berupa negosiasi antara keluarga calon mempelai laki-laki dengan keluarga calon mempelai perempuan berkenaan dengan pembayaran ajikrame dan pisuke.

\section{Rekomendasi}

Mewujudkan perdamaian untuk menegakkan keadilan merupakan hal yang wajib dalam ajaran Islam. Dalam mengupayaakan perdamaian tersebut, Islam menuntun untuk mewujudkannya dengan cara musyawarah, karena dalam musyawarah memuat unsur persaudaraan dan tolong menolong dalam memecahkan persoalan di antara para pihak yang bersengketa, hal ini sesuai dengan firman Allah dalam Surat Asy-Syura ayat 38 yang menyatakan bahwa urusan mereka diputuskan dengan musyawarah antara mereka.

\section{DAFTAR PUSTAKA \\ Buku:}

Basyir, Ahmad Azhar, 2004, Hukum Perkawinan Islam, Yogyakarta: UII Press.

Bartholomew, Jhon Ryan, 2001, Alif Lam Mim: Recording Islam, Modernity and Traditional in an Indonesia Kampung, alih bahasa, Imron Rosyidi, Alif Lam Mim:Kearifan Masyarakat Sasak, Yogyakarta: Tiara Wacana.

Budiwanti, Erni, 2000, Islam Sasak Wetu Telu Versus Waktu Lima, Yogyakarta: LKIS.

Kaharudin, 2007, "Perkawinan Adat Merariq (Kawin Lari) Pada Masyarakat Sasak dalam Prespektif Hukum Perkawinan Islam di Nusa Tenggara Barat", Media Hukum, Vol. 19.

Darmawan, Lalu, 2006, Sistem Perkawinan Masyarakat Sasak (Interpretasi atas Dialetika Agama dengan Tradisi Merarik Masyarakat Lombok Nusa Tenggara Barat), Yogyakarta: Skripsi UIN Sunan Kalijaga.

Wacana, Lalu, dkk., 1991, Sejarah Kebangkitan Nasional Daerah Nusa Tenggara Barat, Mataram: Departemen Pendidikan dan Kebudayaan.

Soemiyati, 1986, Hukum Perkawinan Islam dan Undang-Undang Perkawinan (Undang-Undang Nomor 1 Tahun 1974 tentang Perkawinan), Yogyakarta: Liberty.

Sudirman, 2007, Gumi Sasak dalam Sejarah, Lombok Timur: Yayasan Budaya Sasak Lestari. 
Tim Peneliti Depdikbud, 1978/1979, Adat dan Upacara Perkawinan Daerah Nusa Tenggara Barat, Departemen Pendidikan dan Kebudayaan Pusat Penelitian Sejarah dan Budaya Proyek Penelitian dan Catatan Kebudayaan Daerah.

Saputro, Widodo Dwi dkk., 2000, Balai Mediasi

Desa, Perluasan Akses Hukum dan Keadilan untuk Rakyat, Jakarta: LP3ES \& NZAID.
Hidayah, Zulyani, 1996, Ensiklopedi Suku Bangsa Indonesia, Jakarta: LP3ES.

Subekti, 2008, Kitab Undang-Undang Hukum Perdata, Jakarta: Paradya Paramita.

\section{Website:}

www.badilag.net 